\title{
A Patient with Nonketotic Hyperglycinemia: Biochemical Findings and Therapeutic Approaches
}

\author{
J. M. F. Trujbels, ${ }^{[25]}$ L. A. H. Monnens, S. P. M. van der Zee, J. A. Th. Vrenken, \\ R. C. A. Sengers, and E. D. A. M. Schretlen \\ Department of Pediatrics, University of Nijmegen, Nijmegen, The Netherlands
}

\begin{abstract}
Extract
High voltage paper electrophoresis of urine and quantitative amino acid analysis of serum revealed a greatly increased excretion of glycine as well as hyperglycinemia in a patient on the 7 th day of life. The cerebrospinal fluid of the infant showed a marked increase in isoleucine concentration as well as elevation of the glycine level. After establishment of the enzymic defect in a liver biopsy with the aid of $\left(1-{ }^{14} \mathrm{C}\right)$ glycine and $\left(2{ }^{14} \mathrm{C}\right)$ glycine, several therapeutic approaches have been performed which were based, among other things, on replenishment of the $\mathrm{C}_{1}$ units pool. Administration of compounds such as leucovorin ( $N^{5}$-formyl tetrahydrofolate (THF)), methionine, choline, and formate did not result in a normalization of the serum glycine level. During treatment with methionine $(350 \mathrm{mg} / \mathrm{kg} / 24 \mathrm{hr})$ a strong hypermethioninemia $(1,240 \mu \mathrm{mol} / \mathrm{liter})$ and sarcosinemia $(5,180 \mu \mathrm{mol} / \mathrm{liter})$ developed. A supply of pyridoxine, a precursor of pyridoxal phosphate, the latter being a cofactor in the glycine cleavage system, did not influence the serum glycine level. It was concluded that our patient did not show a deficiency of $N^{5}, N^{10}$-methylene-THF as a result of a defective glycine cleavage system.
\end{abstract}

\section{Speculation}

In spite of comprehensive investigations which concerns patients who suffer from nonketotic hyperglycinemia, additional studies are required to enhance our knowledge of the biochemical disturbance in these patients. This will provide new therapeutic approaches which are urgently desired, as no efficacious measures are available now.

\section{Introduction}

Nonketotic hyperglycinemia is a rare inborn error of metabolism, biochemically characterized by increased concentrations of glycine in blood, urine, and cerebrospinal fluid. Nonketotic hyperglycinemia, which was first described by Gerritsen et al. [14], is considered to be a primary defect in the metabolism of glycine. Moreover, elevated concentrations of glycine in plasma have been found in methylmalonic acidemia [16], propionic acidemia [4], isovaleric acidemia [1], and carbamylphosphate synthetase deficiency [12].

In four patients suffering from nonketotic hyperglycinemia, the defect in the glycine cleavage system was demonstrated in liver biopsies $[10,21]$ and in three patients the disturbed conversion of glycine to serine was established in vivo $[3,6]$.

The purpose of this report is to present a patient with nonketotic hyperglycinemia especially concerning 
amino acid analyses, biochemical investigations, and the results of several therapeutic approaches.

\section{Case Report}

The patient, a girl, the third child in a family, was born December 22th, 1969. The parents and the sibs, a boy born in 1964 and a girl, born in 1967, are healthy. No miscarriages occurred. Pregnancy was uneventful and a normal delivery occurred in the 38 th week of gestation. Birthweight was $2,570 \mathrm{~g}$. Until the end of the 2 nd day of life no abnormality was noted. At that time she sucked poorly and began to have signs and symptoms of irritability and somnolence. On the following days the patient became quieter and was admitted to a hospital on the 5th day of life. At that time she reacted poorly to stimuli and was hypotonic. She exhibited frequent myoclonic seizures; however, breathing was still adequate. Oral humanized milk feeding was stopped and glucose and salt solutions were administered intravenously. She continued to exhibit muscular jerks. Anticonvulsive therapy was instituted. From the 7 th day of life human milk was given. Hyperglycinemia and hyperglycinuria were found at our laboratory. The patient was admitted to our hospital at January 9th, 1970. On physical examination she was essentially normal except that neurologically she was lethargic with no grasp, Moro, and deep tendon reflexes. There were no signs of increased intracranial pressure. She showed myoclonic seizures frequently. The electrocardiogram (EEG) showed alternately short paroxysm and periods of low voltage activity. At that time, treatment with sodium benzoate was started, with a low protein diet ( $1 \mathrm{~g}$ protein $/ \mathrm{kg} / 24$ $\mathrm{hr}$ ). At the age of 5 weeks a synthetic diet free in glycine and serine was given supplemented with $25 \mathrm{ml}$ humanized milk ( $7 \mathrm{mg}$ glycine). After a short period, in which muscular tonicity varied greatly, she became more hypertonic with exaggerated deep tendon reflexes.

\section{Findings at Age of 1 Year}

The patient's weight was 7,500 g, height $66 \mathrm{~cm}$, and head circumference $42 \mathrm{~cm}$. She did not follow with her eyes. She was severely retarded and had no social responses. The muscle tone was still increased. Tendon reflexes were exaggerated. She still exhibited myoclonic seizures. The EEG showed the typical pattern of hypsarrhythmia.

Normal laboratory data were found for blood $\mathrm{pH}$,
$\mathrm{pCO}_{2}$, blood base excess, serum bicarbonate, sodium, potassium, chloride, urea, hemoglobin, hematocrit, erythrocytes, leucocytes, and platelet counts. Ketoacidosis and ketonuria were never observed. The results of amino acid analyses at different ages are shown in Table I. Ammonia in blood was determined once at the age of about 3 years; a normal value was found $(1.3 \mu \mathrm{g} / \mathrm{ml})$. Oxalic acid excretion at the age of 9 months was less than $10 \mathrm{mg} / 24 \mathrm{hr}$.

\section{Methods}

Qualitative amino acid analysis of the patient's urine was performed by high voltage paper electrophoresis [22] on Whatman $3 \mathrm{MM}$ filter paper, $40 \times 20 \mathrm{~cm}$, for $20 \mathrm{~min}$ at $100 \mathrm{~V} / \mathrm{cm}$ in formic acid-acetic acid-water (50/150/850, v/v), pH 2.0. Quantitative amino acid analyses of serum, cerebrospinal fluid, and urine of the patient were performed by elution chromatography with a Beckman/Spinco Unichrom amino acid analyzer [23]. Deproteinization of the samples was carried out with sulfosalicylic acid $(5 \% \mathrm{w} / \mathrm{v})$.

Liver biopsy was taken with a Menghini needle under local anesthesia. A control liver biopsy was obtained surgically. The glycine cleavage system in liver was investigated according to a minor modification of the method described by De Groot et al. [10]. The liver biopsy from the patient was preserved at $-80^{\circ}$ and that from the control subject in liquid nitrogen before use. The biopsy specimens were homogenized in a Potter-Elvehjem homogenizer in $0.05 \mathrm{M}$ potassium phosphate buffer, pH 7.5. A rat liver homogenate was prepared in the same manner. The incubation mixtures contained, in a final volume of $0.6 \mathrm{ml}$, (1$\left.{ }^{14} \mathrm{C}\right)$ glycine $(2.1 \mu \mathrm{mol})$ and liver homogenate containing $25 \mathrm{mg}$ wet weight for the control liver and rat liver and an unknown amount of the patient's liver. Incubation was performed in $30-\mathrm{ml}$ glass scintillation vials, sealed by rubber stoppers, containing two small glass tubes, one fitting inside the other [13]. The inner tube contained $0.5 \mathrm{ml}$ Hyamine. The scintillation vials contained the components of the reaction mixture. After incubation for $3 \mathrm{hr}$ at $37^{\circ}, 0.2 \mathrm{ml} 2 \mathrm{~N} \mathrm{HCl}$ was added by injection through the rubber stopper and the vials were kept at $37^{\circ}$ for another hour. Thereafter, the stoppers were removed and the inner glass tubes containing Hyamine were removed from the vials and transferred to scintillation vials containing $15 \mathrm{ml}$ scintillation fluid (4 g 2,5-diphenyloxazole (PPO) and $0.1 \mathrm{~g}$ dimethyl 1,4-bis[(diphenyloxazolyl]benzene 
(POPOP) in a mixture of $500 \mathrm{ml}$ toluol and $500 \mathrm{ml}$ ethyl-Cellosolve). Counting was performed in a scintillation counter. In this manner the radioactivity of ${ }^{14} \mathrm{CO}_{2}$ released from $\left(\mathrm{I}^{14} \mathrm{C}\right)$ glycine was determined.

The rates of incorporation of ${ }^{14} \mathrm{C}$ from (1$\left.{ }^{14} \mathrm{C}\right)$ glycine and $\left(2 \cdot{ }^{14} \mathrm{C}\right)$ glycine [24] into serine by liver homogenates have been measured in centrifuge tubes containing the same incubation mixture as was used for determination of ${ }^{14} \mathrm{CO}_{2}$. Two separate experiments have been performed either with $\left(1^{14} \mathrm{C}\right)$ glycine or (2$\left.{ }^{14} \mathrm{C}\right)$ glycine. After incubation for $3 \mathrm{hr}$ at $37^{\circ}$ the reaction was terminated by addition of $0.6 \mathrm{ml}$ of $0.1 \mathrm{~N}$ acetic acid to the incubation mixtures. After placing the tubes for $2 \mathrm{~min}$ in a boiling water bath the precipitated proteins were removed by centrifugation for 10 $\min$ at $2,000 \times g$. For examination of control and rat liver, $0.2 \mathrm{ml}$ supernatant was subjected to high voltage paper electrophoresis on Whatman no. 3MM filter paper under the same conditions as described before. Thereafter, the strips were dried at $95^{\circ}$ and scanned for radioactivity with the aid of a strip counter. The strips were cut into pieces which contained either labeled glycine or serine. The radioactivity of both amino acids was determined with a scintillation counter, using $15 \mathrm{ml}$ liquid scintillation solvent for each vial. For examination of the patient's liver, labeled glycine and serine were separated with the aid of an automatic amino acid analyzer. The supernatant of the deproteinized incubation mixture was acidified to $\mathrm{pH} 2$ and a 1-mI aliquot of this mixture was applied to the amino acid analyzer. The fractions containing either serine or glycine were collected separately and evacuated to dryness and the residues were dissolved in $1 \mathrm{ml}$ distilled water. These solutions were added to 20 $\mathrm{ml}$ liquid scintillation solvent and counted for radioactivity.

\section{Results}

\section{Amino Acid Analyses}

More than 250 quantitative analyses of amino acids in the serum of this patient have been performed. Significant data are shown in Table I. The most marked abnormality was the strong hyperglycinemia (normal values to $450 \mu \mathrm{mol} /$ liter). The other acidic and neutral amino acids were present in almost normal concentrations. The basic amino acids have been determined once and were found to be normal. Table $I$ also shows the amino acid concentration in the cerebrospinal fluid of this patient. A remarkable increase in the glycine level was found (about sevenfold). In the other amino acids the concentration of isoleucine was markedly raised (about fivefold).

At the age of 11 months the tubular reabsorption of acidic and neutral amino acids was determined in the patient, who was treated at that time with sodium

Table I. Concentrations of amino acids in serum at various ages and in cerebrospinal fluid (CSF) at age of 14 months

\begin{tabular}{|c|c|c|c|c|c|c|}
\hline & \multicolumn{5}{|c|}{ Serum, $\mu \mathrm{mol} / \mathrm{liter}$} & \multirow{2}{*}{$\mathrm{CSF}^{1}$} \\
\hline & 28 Days $^{2}$ & 83 Days $^{3}$ & 13 Months $^{4}$ & 25 Months $^{5}$ & Controls, mean $\pm \mathrm{sD}$ & \\
\hline Hydroxyproline & Trace & Trace & Trace & Trace & & 0 \\
\hline Aspartic acid & Trace & Trace & Trace & 21 & $45 \pm 30$ & 0 \\
\hline Threonine & 144 & 279 & 264 & 164 & $161 \pm 68$ & 50 \\
\hline Serine & 168 & 206 & 171 & 154 & $182 \pm 56$ & 50 \\
\hline Proline & 140 & 226 & & 171 & $273 \pm 119$ & 0 \\
\hline Glutamic acid & & & 55 & 66 & $172 \pm 106$ & Trace \\
\hline Citrulline & & & 52 & 36 & $31 \pm 12$ & Trace \\
\hline Glycine & 770 & 1,540 & 1,070 & 835 & $260 \pm 90$ & 101 \\
\hline Alanine & 262 & 595 & 940 & 437 & $422 \pm 136$ & 51 \\
\hline Valine & 131 & 163 & 145 & 142 & $257 \pm 99$ & 28 \\
\hline Cystine & & & & & & 0 \\
\hline Methionine & & 27 & 32 & 28 & $38 \pm 18$ & Trace \\
\hline Isoleucine & 33 & 152 & 79 & 54 & $86 \pm 36$ & 24 \\
\hline Leucine & 82 & 172 & 98 & 77 & $149 \pm 64$ & 25 \\
\hline Tyrosine & 39 & 89 & 45 & 63 & $89 \pm 40$ & 19 \\
\hline Phenylalanine & 57 & 68 & 29 & 46 & $79 \pm 31$ & 14 \\
\hline
\end{tabular}

1 Patient received $172 \mathrm{mg}$ sodium benzoate and $36 \mathrm{mg}$ glycine $/ \mathrm{kg} / 24 \mathrm{hr}$.

2 Patient received $185 \mathrm{mg}$ sodium benzoate and $14 \mathrm{mg}$ glycine $/ \mathrm{kg} / 24 \mathrm{hr}$.

${ }^{3}$ Patient received $280 \mathrm{mg}$ sodium benzoate, $0.95 \mathrm{mg}$ leucovorin, and $2.2 \mathrm{mg}$ glycine $/ \mathrm{kg} / 24 \mathrm{hr}$.

4 Patient received $120 \mathrm{mg}$ sodium benzoate and $0.93 \mathrm{mg}$ glycine $/ \mathrm{kg} / 24 \mathrm{hr}$.

5 Patient received $130 \mathrm{mg}$ sodium benzoate and $3.9 \mathrm{mg}$ glycine $/ \mathrm{kg} / 24 \mathrm{hr}$. 
Table II. Production of ${ }^{14} \mathrm{CO}_{2}$ from $\left(1-{ }^{14} \mathrm{C}\right)$ glycine and rates of incorporation of ${ }^{14} \mathrm{C}$ from $\left(1-{ }^{14} \mathrm{C}\right)$ glycine and $\left(2-{ }^{14} \mathrm{C}\right)$ glycine into serine by liver homogenates of the patient, human control subject, and rat

\begin{tabular}{|c|c|c|c|c|}
\hline \multirow{2}{*}{ Liver source } & \multirow{2}{*}{${ }^{14} \mathrm{CO}_{2}, \mathrm{cpm} / \mathrm{mg}$ wet wt $/ \mathrm{hr}$} & \multicolumn{2}{|c|}{ 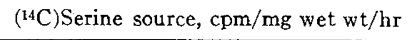 } & \multirow{2}{*}{$\begin{array}{c}\text { Incorporation rates for } \\
\left(2{ }^{-14} \mathrm{C}\right) \text { glycine } /(1-14 \mathrm{C}) \text { glycine }\end{array}$} \\
\hline & & $(1-14 \mathrm{C})$ Glycine & $(2-14 \mathrm{C})$ Glycine & \\
\hline Patient & Not detectable & $1,036^{1}$ & $1,164^{1}$ & 1.1 \\
\hline Human control subject & 61 & 137 & 198 & 1.5 \\
\hline Rat & 170 & 342 & 515 & 1.5 \\
\hline
\end{tabular}

${ }^{1}$ Calculated for the whole liver biopsy (weight unknown).

benzoate $(900 \mathrm{mg} / 24 \mathrm{hr})$ and methionine $(480 \mathrm{mg} / 24$ hr) on a diet nearly devoid of glycine and serine. The calculation of the tubular reabsorption was performed from the amino acid concentrations in the blood and urine of the patient and from the glomerular filtration rate, which was determined as the clearance of inulin. Normal values for the tubular reabsorption of acidic and neutral amino acids including glycine were found.

\section{Glycine Cleavage System}

The enzymic defect in the patient has been demonstrated in vitro by measurement of the production of ${ }^{14} \mathrm{CO}_{2}$ from $\left(1-{ }^{14} \mathrm{C}\right)$ glycine and of the rates of incorpo- ration of ${ }^{14} \mathrm{C}$ from $\left(1-{ }^{14} \mathrm{C}\right)$ glycine and $\left(2-{ }^{14} \mathrm{C}\right)$ glycine into serine by liver homogenate. From Table II it appears that no detectable amount of ${ }^{14} \mathrm{CO}_{2}$ was formed from $\left(1-{ }^{14} \mathrm{C}\right)$ glycine, by this patient's liver, whereas a significant ${ }^{14} \mathrm{CO}_{2}$ production was observed by incubation of human or rat liver with $\left(1-{ }^{14} \mathrm{C}\right)$ glycine. The ratio of the rates of incorporation of ${ }^{14} \mathrm{C}$ from (2$\left.{ }^{14} \mathrm{C}\right)$ glycine and $\left(1-{ }^{14} \mathrm{C}\right)$ glycine into serine was found to be about 1 for the liver of the patient, whereas a value of about 1.5 was found for this ratio for human control and rat liver. These findings are consistent with a defect in the formation of $N^{5}, N^{10}$-methylene-THF from glycine (Fig. 1).

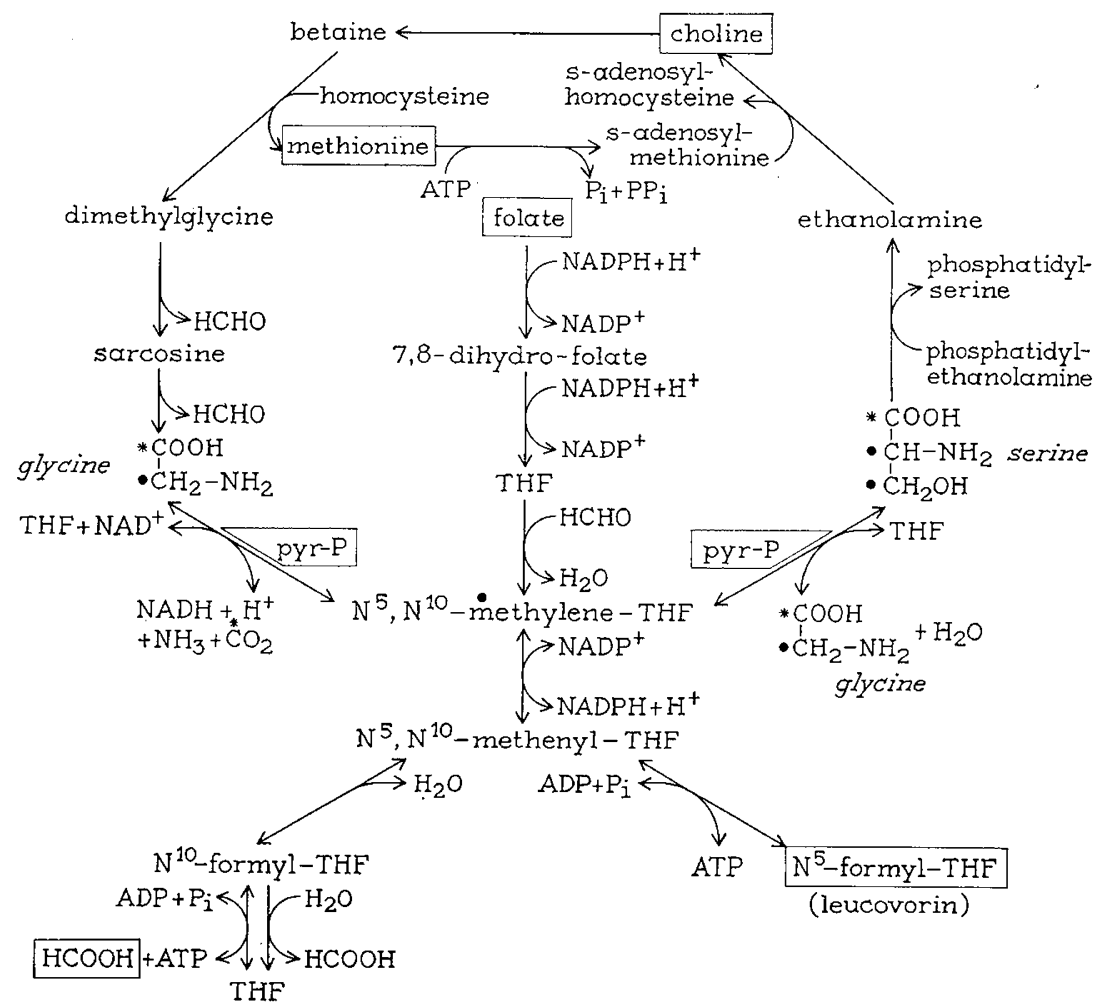

Fig. 1. Metabolism of glycine and some therapeutic trials of a patient with nonketotic hyperglycinemia. Relation between therapeutic approaches $(\square)$ and glycine metabolism. THF: tetrahydrofolate. 


\section{Therapeutic Approaches}

Several therapeutic approaches were based upon conjugation of glycine and excretion of the conjugates, or restriction of glycine and serine in the diet, or correction of the $\mathrm{C}_{1}$ units pool which might be diminished as a result of defective cleavage of glycine.

\section{Conjugation of Glycine}

This kind of treatment is based upon conjugation of glycine with either benzoate or salicylate and subsequent excretion of the conjugates in urine. Treatment with sodium benzoate was started during the 1st month of life and was continued in a dose varying from 100 to $300 \mathrm{mg} / \mathrm{kg} / 24 \mathrm{hr}$ for about 3 years except for a few days when salicylate was given. We are not able to describe adequately the influence of this treat- ment on the glycine level in blood, inasmuch as the number of glycine values obtained without any treatment is too small to permit conclusions.

\section{Restriction of Glycine Intake}

The patient was fed a diet with a glycine intake which varied from 0.7 to $35.6 \mathrm{mg} / \mathrm{kg} / 24 \mathrm{hr}$. No significant decrease of the level of glycine in serum was observed with decreasing intake of glycine daily during a period in which the patient received daily 1,500 mg sodium benzoate (Table III).

\section{Supply of $C_{1}$ Units}

A different kind of treatment was based upon supplying $\mathrm{C}_{1}$ units [10]. Leucovorin ( $N^{5}$-formyl-THF), which can be converted into $N^{5}, N^{10}$-methylene-THF

Table III. Influence of therapeutic trials on glycine level in serum

\begin{tabular}{|c|c|c|c|c|c|}
\hline Treatment, $\mathrm{mg} / \mathrm{kg} / 24 \mathrm{hr}$ & & $\begin{array}{l}\text { Serum glycine, } \\
\mu \text { mol/liter } \\
(\text { mean } \pm \mathrm{SD})\end{array}$ & $\mathrm{n}$ & $P$ & Dietary or therapeutic conditions \\
\hline Glycine (diet) & $\begin{array}{r}0.7 \\
1.3 \\
3.9 \\
4.9 \\
5.8 \\
.7 \\
395.6\end{array}$ & $\begin{array}{l}687 \pm 137 \\
785 \pm 42 \\
963 \pm 190 \\
803 \pm 228 \\
786 \pm 118 \\
800 \pm 14 \\
723 \pm 135\end{array}$ & $\begin{array}{r}23 \\
6 \\
7 \\
7 \\
12 \\
2 \\
3\end{array}$ & $>0.05$ & Sodium benzoate, $1,500 \mathrm{mg} / 24 \mathrm{hr}$ \\
\hline Leucovorin (i.m.) & $\begin{array}{l}0 \\
0.32 \\
0.96\end{array}$ & $\begin{array}{l}687 \pm 137 \\
743 \pm 188 \\
840 \pm 149\end{array}$ & $\begin{array}{r}23 \\
3 \\
8\end{array}$ & $<0.01$ & $\begin{array}{l}\text { Sodium benzoate, } 1,500 \mathrm{mg} / 24 \mathrm{hr} \text {; glycine, } 7 \\
\mathrm{mg} / 24 \mathrm{hr}\end{array}$ \\
\hline Methionine (orally) & $\begin{array}{r}0 \\
45 \\
80\end{array}$ & $\begin{array}{l}937 \pm 168 \\
883 \pm 217 \\
827 \pm 226\end{array}$ & $\begin{array}{r}15 \\
7 \\
20\end{array}$ & $>0.05$ & $\begin{array}{l}\text { Sodium benzoate, } 900 \mathrm{mg} / 24 \mathrm{hr} \text {; glycine, } 7 \\
\mathrm{mg} / 24 \mathrm{hr}\end{array}$ \\
\hline Choline (orally) & $\begin{array}{r}0 \\
71 \\
86 \\
107\end{array}$ & $\begin{array}{l}787 \pm 113 \\
868 \pm 84 \\
750 \\
946 \pm 76\end{array}$ & $\begin{array}{r}13 \\
5 \\
1 \\
5\end{array}$ & $<0.01$ & $\begin{array}{l}\text { Sodium benzoate, } 1,500 \mathrm{mg} / 24 \mathrm{hr} ; \text { glycine, } 75 \\
\mathrm{mg} / 24 \mathrm{hr}\end{array}$ \\
\hline Sodium formate (orally) & $\begin{array}{r}0 \\
26 \\
42\end{array}$ & $\begin{array}{l}937 \pm 168 \\
853 \pm 117 \\
804 \pm 123\end{array}$ & $\begin{array}{r}15 \\
8 \\
5\end{array}$ & $0.025 \ll 0.05$ & $\begin{array}{l}\text { Sodium benzoate, } 875 \mathrm{mg} / 24 \mathrm{hr} \text {; glycine, } 7 \\
\mathrm{mg} / 24 \mathrm{hr}\end{array}$ \\
\hline Pyridoxine (orally) & $\begin{array}{r}0 \\
27\end{array}$ & $\begin{array}{l}937 \pm 168 \\
822 \pm 30\end{array}$ & $\begin{array}{r}15 \\
4\end{array}$ & $>0.1$ & $\begin{array}{l}\text { Sodium benzoate, } 900 \mathrm{mg} / 24 \mathrm{hr} \text {; glycine, } 7 \\
\mathrm{mg} / 24 \mathrm{hr}\end{array}$ \\
\hline Pyridoxine (orally) & $\begin{array}{r}0 \\
15 \\
28\end{array}$ & $\begin{aligned} 827 & \pm 226 \\
1,051 & \pm 76 \\
810 & \pm 144\end{aligned}$ & $\begin{array}{r}20 \\
7 \\
6\end{array}$ & $>0.05$ & $\begin{array}{l}\text { Sodium benzoate, } 900 \mathrm{mg} / 24 \mathrm{hr} ; \text { glycine, } 7 \\
\mathrm{mg} / 24 \mathrm{hr} \text {; methionine, } 480 \mathrm{mg} / 24 \mathrm{hr}\end{array}$ \\
\hline Folic acid (orally) & $\begin{array}{l}0 \\
1.1\end{array}$ & $\begin{array}{r}804 \pm 123 \\
1,053 \pm 180\end{array}$ & $\begin{array}{l}5 \\
9\end{array}$ & $0.01 \ll 0.02$ & $\begin{array}{l}\text { Sodium benzoate, } 900 \mathrm{mg} / 24 \mathrm{hr} \text {; sodium for- } \\
\text { mate, } 180 \mathrm{mg} / 24 \mathrm{hr} \text {; glycine, } 7 \mathrm{mg} / 24 \mathrm{hr}\end{array}$ \\
\hline
\end{tabular}

1 Based on regression analysis or Student $t$ test. 
(Fig. 1) was given intramuscularly in a dosage of 0.32 and $0.96 \mathrm{mg} / \mathrm{kg} / 24 \mathrm{hr}$ (Table III). A small but significant increase of the level of glycine in serum was observed.

Treatment of nonketotic hyperglycinemia patients with methionine as performed by De Groot et al. [10] is also based on providing the organism with a suffi. cient amount of $\mathrm{C}_{1}$ units. Our patient received methionine combined with sodium benzoate $(900 \mathrm{mg} / 24 \mathrm{hr}$ ) and a glycine intake of $7 \mathrm{mg} / 24 \mathrm{hr}$. From the results presented in Table III, it can be concluded that treatment with methionine did not result in a significant decrease of the serum glycine level. The dosage of methionine was increased to $350 \mathrm{mg} / \mathrm{kg} / 24 \mathrm{hr}$ but hypermethioninemia $(1,240 \mu \mathrm{mol} /$ liter $)$ and sarcosinemia $(5,180 \mu \mathrm{mol} /$ liter $)$ were seen in that period.

Treatment of the patient with choline represents a third method for donation of $\mathrm{C}_{1}$ units. Choline was administered to the patient during a constant daily sodium benzoate $(1,500 \mathrm{mg})$ and glycine $(75 \mathrm{mg})$ intake. We established a significant increase of the glycine level with increasing choline dosages.

Only one kind of treatment resulted in a small but significant decrease of the serum glycine level, namely, administration of sodium formate (Table III) with a daily intake of sodium benzoate $(875 \mathrm{mg})$ and glycine (7 mg); however, no normalization of the glycine level occurred.

\section{Supply of Cofactors}

Because pyridoxal phosphate [19] participates in the glycine cleavage system, pyridoxine was given along with a constant daily sodium benzoate $(900 \mathrm{mg})$ and glycine $(7 \mathrm{mg})$ intake either with or without administration of $480 \mathrm{mg}$ methionine/24 hr (Table III). No dependence on pyridoxine was observed.

\section{Supply of Folic Acid}

Treatment of the patient with folic acid, a precursor of $N^{5}, N^{10}$-methylene-THF, was performed only in conjunction with a constant daily intake of sodium benzoate $(900 \mathrm{mg})$, glycine $(7 \mathrm{mg})$, and sodium formate (180 mg). A significant increase of the serum glycine level was the result.

\section{Discussion}

Gerritsen et al. [14] supposed originally that nonketotic hyperglycinemia was associated with a defect in the glycine oxidase system; however, later such a defect was ruled out [15]. Thereafter, Ando et al. [3] demon- strated a defect in vivo in the formation of ${ }^{14} \mathrm{CO}_{2}$ from $\left(1-{ }^{14} \mathrm{C}\right)$ glycine and a complete deficiency in the conversion of $\left(2-{ }^{14} \mathrm{C}\right)$ glycine to $\left(3^{-14} \mathrm{C}\right)$ serine. Yoshida et al. [21] demonstrated a deficiency of the glycine cleavage system in the liver of a patient who suffered from nonketotic hyperglycinemia. The amount of ${ }^{14} \mathrm{CO}_{2}$ formed from $\left(\mathrm{I}^{-14} \mathrm{C}\right)$ glycine was only $8 \%$ of the mean value obtained for control subjects. The amount of $\left({ }^{14} \mathrm{C}\right)$ serine formed after incubation either with (1$\left.{ }^{14} \mathrm{C}\right)$ glycine or $\left(2-{ }^{14} \mathrm{C}\right)$ glycine was also very small. In their patient a ratio of 1.2 was found between the rates of incorporation of $\left(2-{ }^{14} \mathrm{C}\right)$ glycine and $\left(1-{ }^{14} \mathrm{C}\right)$ glycine into $\left({ }^{14} \mathrm{C}\right)$ serine, whereas a mean ratio of 1.8 was found for control subjects. Moreover, a nearly equal amount of ${ }^{14} \mathrm{CO}_{2}$ was formed either from $\left({ }^{-14} \mathrm{C}\right)$ glycine or $(2$ $\left.{ }^{14} \mathrm{C}\right)$ glycine. These experiments confirm the in vivo findings of Ando et al. [3]. From the diminished ratio of the rates of incorporation of $\left(1{ }^{14} \mathrm{C}\right)$ glycine into serine it might be concluded that the formation of $N^{5}, N^{10}$ methylene-THF from glycine is very important for synthesis of serine from glycine.

Baumgartner et al. [6] also investigated a patient with nonketotic hyperglycinemia. After intravenous injection of $\left(2-{ }^{14} \mathrm{C}\right)$ glycine and isolation of serine from plasma, they found, as compared with control subjects, a strongly diminished, but detectable conversion to (3$\left.{ }^{14} \mathrm{C}\right)$ serine, data in contrast to that of Ando et al. [3], who found virtually no conversion. Baumgartner et al. [7] postulated the hypothesis of a number of different forms of nonketotic hyperglycinemia. Baumgartner et al. [7] investigated the conversion of propionylCoA to methylmalonyl-CoA and of methylmalonylCoA to succinyl-CoA in fibroblasts and liver homogenate of a patient with nonketotic hyperglycinemia. They found normal conversions and concluded that "nonketotic hyperglycinemia" is a disease distinct from the "ketotic hyperglycinemia" in which one of the previously mentioned conversions does not function. Previously [17] however, a major defect in the conversion of glycine to serine was established after intravenous injection of $\left(2{ }^{3} \mathrm{H}\right)$ glycine in a patient who suffered from hyperglycinemia coupled with ketosis and metabolic acidosis.

Recently, Ando et al. [2] demonstrated in vivo that the conversion of $\left(\mathrm{I}^{-14} \mathrm{C}\right)$ glycine to $\mathrm{CO}_{2}$ was defective in three patients with ketotic hyperglycinemia just as in the nonketotic hyperglycinemia patients [3], but, in contrast to the latter, a normal conversion of (2$\left.{ }^{14} \mathrm{C}\right)$ glycine to $\left(3-{ }^{14} \mathrm{C}\right)$ serine was found after one of the patients received injections of $\left(2^{-14} \mathrm{C}\right)$ glycine. From these findings, it might be concluded that a defect in the 
conversion of glycine to $N^{5}, N^{10}$-methylene-THF results in a defective conversion of glycine to serine in the nonketotic but not in the ketotic hyperglycinemia. A possible explanation for this discrepancy might be the existence of one or more alternate pathways leading to $N^{5}, N^{10}$-methylene-THF which could be stimulated in ketotic hyperglycinemia.

De Groot et al. [10] studied three patients with nonketotic hyperglycinemia in vitro. In liver biopsies they demonstrated a defect in the glycine cleavage system. The authors mentioned that the defective enzyme has a control position in the supply of $\mathrm{C}_{1}$ units which are necessary for synthetic reactions.

Up to now, several therapeutic measures have been applied to reduce the glycine levels in blood. Rampini et al. [18] treated one patient from the age of 6 months with a diet containing only $0.5 \mathrm{~g}$ of protein $/ \mathrm{kg} / 24 \mathrm{hr}$. After a period of 3 weeks with unchanged glycine levels, a distinct reduction of the glycine levels was observed with a complete normalization after 2 months. Tada et al. [20] treated their patient at the age of 16 months with $3 \mathrm{mg}$ leucovorin every day for a week by intramuscular injections, but they found no change in serum glycine levels. However, significant but temporary decrease in serum glycine concentration was obtained after treatment with $30 \mathrm{mg}$ leucovorin given intravenously by drip infusion. Baumgartner et al. [6] could reduce glycine concentration in plasma from 1,600 $\mu \mathrm{mol} /$ liter to $530 \mu \mathrm{mol} /$ liter by exchange transfusion. Benzoate treatment resulted in a significant but small reduction of the glycine level on a low protein diet $(0.5-0.8 \mathrm{~g} / \mathrm{kg} / 24 \mathrm{hr})$. Reduction of the dietary protein content did not result in a significant change of the glycine level in plasma. Bachmann et al. [5] also obtained a significant but temporary decrease of the level of glycine in plasma by exchange transfusion. The treatment of their patient with methionine $(300 \mathrm{mg} / 24 \mathrm{hr})$ or benzoic acid $(0.5 \mathrm{~g} / 24 \mathrm{hr}) \mathrm{did}$ not prevent early death. Ferdinand et al. [11] described a patient with nonketotic hyperglycinemia who survived for 3 years on a protein-deficient diet; however, mental retardation could not be prevented.

One of the most extensive studies concerning treatment of nonketotic hyperglycinemia patients was performed by De Groot et al. [10] and by De Groot [9]. They treated patients with a synthetic diet which did not contain glycine and serine. In some, but not all cases, a decrease in glycine level in blood was obtained but mental retardation still developed. Based on the assumption that a shortage of $\mathrm{C}_{1}$ units existed in the patients, De Groot [9] treated a patient with methionine and observed a marked decrease of the glycine level in the blood. This decline in glycine concentration could also be explained in terms of a decrease in supply of serine [8].

Treatment of another patient with choline did not influence glycine levels but a reduction to low-normal levels of serine was seen.

As described before, our patient was treated either with compounds which could provide $\mathrm{C}_{1}$ units, such as leucovorin, methionine, choline, and formate or compounds which could be considered to be precursors of $N^{5}, N^{10}$-methylene-THF, e.g., folate (Fig. 1). A slight but significant decrease of the glycine level in serum was obtained only during treatment with sodium formate (Table III). Therefore, it appeared likely that our patient did not show a deficiency of $N^{5}, N^{10}$-methyleneTHF as a result of a defective glycine cleavage system, inasmuch as no real improvement of the biochemical and clinical conditions was observed during different kinds of treatment.

In contrast to the data of De Groot et al. [10], a normal tubular reabsorption of glycine was found during treatment with methionine.

From this study it appears that further investigations will be necessary in order to find a treatment which will restore the biochemical disturbances and prevent physical and mental retardation. Moreover, fundamental biochemical research will help us to clarify the previously mentioned problems of metabolism of gly. cine in nonketotic and ketotic hyperglycinemia patients.

\section{Summary}

A patient suffering from nonketotic hyperglycinemia has been investigated for 3 years. The enzyme defect has been demonstrated by incubation of a homogenate of a liver biopsy with $(1-14 \mathrm{C})$ glycine and $\left(2-{ }^{14} \mathrm{C}\right)$ glycine and measurement of the radioactivity of ${ }^{14} \mathrm{CO}_{2}$ released from $\left(1^{-14} \mathrm{C}\right)$ glycine and of the ratio of the rates of incorporation of $\left(2-{ }^{14} \mathrm{C}\right)$ glycine and $\left(1-{ }^{14} \mathrm{C}\right)$ glycine into serine. The serum of the patient showed a marked increase in glycine level only, whereas a great elevation of both glycine and isoleucine levels was found in the cerebrospinal fluid. Several therapeutic approaches have been attempted which were based upon either conjugation of glycine and excretion of the conjugates (benzoate and salicylate), or restriction of glycine intake, supply of $\mathrm{C}_{1}$ units (leucovorin, methionine, cho- 
line, and formate), supply of a cofactor (pyridoxine), or supply of folate. None of the measures mentioned previously resulted in a real improvement of the clinical or biochemical disturbances.

\section{References and Notes}

1. Ando, T., Klingberg, W. G., Ward, A. N., Rasmussen, K., and Nyнал, W. L.: Isovaleric acidemia presenting with altered metabolism of glycine. Pediat. Res., 5: 748 (1971a).

2. Ando, T., Nyhan, W. L., Connor, J. D., Rasmussen, K., Donnell, G., Barnes, N., Cottom, D., and Hull, D.: The oxidation of glycine and propionic acid in propionic acidemia with ketotic hyperglycinemia. Pediat. Res., 6: 576 (1972).

3. Ando, T., Nyhan, W. L., Gerritsen, T., Gong, L., Heiner, D. C., AND BRAX, P. F.: Metabolism of glycine in the nonketotic form of hyperglycinemia. Pediat. Res., 2: 254 (1968).

4. Ando, T., Rasmussen, K., Nyhan, W. L., Donnell, G. N., And Barnes, N. D.: Propionic acidemia in patients with ketotic hyperglycinemia. J. Pediat., 78: 827 (1971).

5. Bachmann, C., Mihatsch, M. J., Baumgartner, R. E., Brechbühler, T., Buhler, U. K., Olafsson, A., Ohnacker, H., AND Wick, H.: Nichtketotische hyperglyzinämie: Perakuter Verlauf im Neugeborenenalter. Helv. Paediat. Acta, 26: 228 (1971).

6. Baumgartner, R., Ando, T., AND Nyhan, W. L.: Nonketotic hyperglycinemia. J. Pediat., 75: 1022 (1969).

7. Baumgartner, E. R., Brechbühler, T., and Wrck, H.: Normal propionate metabolism in "non-ketotic hyperglycinemia." Abstracts of the Annual Meeting of the European Society for Paediatric Research in Heidelberg, No. 58 (1972).

8. Benevenga, N. J., ANd Harper, A. E.: Effect of glycine and serine on methionine metabolism in rats fed diets high in methionine. J. Nutr., 100: 1205 (1970).

9. De Groor, C. J.: Onderzoek van de niet-ketotische hyperglycinaemie; een erfelijke stofwisselingsziekte, M.D. thesis, Groningen (1971).

10. De Groot, C. J., Troelstra, J. A., and Hommes, F. A.: Nonketotic hyperglycinemia: An in vitro study of the glycineserine conversion in liver of three patients and the effect of dietary methionine. Pediat. Res., 4: 238 (1970).

11. Ferdinand, W., Gordon, R. R., ANd Owen, G.: Nonketotic hyperglycinaemia. Clinical findings and amino acid analyses on the plasma of a new case. Clin. Chim. Acta, 30: 745 (1970).

12. Freeman, J. M., Nichorson, J. F., Masland, W. S., Rowland, L. P., and Carter, S.: Ammonia intoxication due to a congenital defect in urea synthesis. J. Pediat., 65: 1039 (1964).

13. Fox, R. M.: A simple incubation flask for ${ }^{14} \mathrm{CO}_{2}$ collection. Anal. Biochem., 41:578 (1971).

14. Gerritsen, T., Kaveggia, E., and Warsman, H. A.: A new type of idiopathic hyperglycinemia with hypooxaluria. Pediatrics, 36: 882 (1965).

15. Gerritsen, T., Nyhan, W. L., RehberG, M. L., and Ando, T.: Metabolism of glyoxylate in nonketotic hyperglycinemia. Pediat. Res., 3: 269 (1969).

16. Morrow, G., III, Barness, L. A., Auerbach, V. H., di George, A. M., ANDo, T., AND Nyhan, W. L.: Observations on the coexistence of methylmalonic acidemia and glycinemia. J. Pediat., 74: 680 (1969).

17. Nyman, W. L., and Childs, B.: Hyperglycinemia. V. The miscible pool and turnover rate of glycine and the formation of serine. J. Clin. Invest., 43: 2404 (1964).

18. Rampini, S., Vischer, D., Curtius, H. C., Anders, P. W., Tancredi, F., Frischknecht, W., ANd Prader, A.: Hereditäre Hyperglycinämie. Helvet. Paediat. Acta, 22: 135 (1967).

19. Sato, T., Kochi, H., Sato, N., and Kxkuchi, G.: Glycine metabolism by rat liver mitochondria. III. The glycine cleavage and the exchange of carboxyl carbon of glycine with bicarbonate. J. Biochem., 65: 77 (1969).

20. Tada, K., Narisawa, K., Yoshida, T., Konno, T., Yokoyama, Y., Nakagawa, H., Tanno, K., Mochizuki, K., Arakawa, T., Yoshida, T., AND KxкUCHI, G.: Hyperglycinemia: a defect in glycine cleavage reaction. Tohoku J. Exp. Med., 98: 289 (1969).

21. Yoshida, T., Krkuchi, G., Tada, K., Narisama, K., and Arakawa, T.: Physiological significance of glycine cleavage system in human liver as revealed by the study of a case of hyperglycinemia. Biochem. Biophys. Res. Commun., 35: 577 (1969).

22. Camag, Muttenz, Switzerland.

23. Beckman/Spinco, Munich, Germany.

24. Radiochemical Centre, Amersham, England.

25. Requests for reprints should be addressed to: J. M. F. TrIJBELS, Ph.D., Department of Pediatrics, University of Nijmegen, The Netherlands.

26. Accepted for publication January 14, 1974. 